\title{
Looking at the Nudibranch Family Myrrhinidae (Gastropoda, Heterobranchia) from a Mitochondrial '2D Folding Structure' Point of View
}

\author{
Giulia Furfaro $^{1, *(D)}$ and Paolo Mariottini ${ }^{2}$ (D) \\ 1 Department of Biological and Environmental Sciences and Technologies—DiSTeBA, University of Salento, \\ I-73100 Lecce, Italy \\ 2 Department of Science, University of Roma Tre, I-00146 Rome, Italy; paolo.mariottini@uniroma3.it \\ * Correspondence: giulia.furfaro@unisalento.it; Tel.: +39-0832-29-8660
}

Citation: Furfaro, G.; Mariottini, P. Looking at the Nudibranch Family Myrrhinidae (Gastropoda,

Heterobranchia) from a

Mitochondrial '2D Folding Structure' Point of View. Life 2021, 11, 583.

https://doi.org/10.3390/life11060583

Academic Editors: Andrea Luchetti and Federico Plazzi

Received: 16 April 2021

Accepted: 17 June 2021

Published: 18 June 2021

Publisher's Note: MDPI stays neutral with regard to jurisdictional claims in published maps and institutional affiliations.

\begin{abstract}
Integrative taxonomy is an evolving field of multidisciplinary studies often utilised to elucidate phylogenetic reconstructions that were poorly understood in the past. The systematics of many taxa have been resolved by combining data from different research approaches, i.e., molecular, ecological, behavioural, morphological and chemical. Regarding molecular analysis, there is currently a search for new genetic markers that could be diagnostic at different taxonomic levels and that can be added to the canonical ones. In marine Heterobranchia, the most widely used mitochondrial markers, COI and 16S, are usually analysed by comparing the primary sequence. The 16S rRNA molecule can be folded into a 2D secondary structure that has been poorly exploited in the past study of heterobranchs, despite 2D molecular analyses being sources of possible diagnostic characters. Comparison of the results from the phylogenetic analyses of a concatenated (the nuclear $\mathrm{H} 3$ and the mitochondrial COI and 16S markers) dataset (including 30 species belonging to eight accepted genera) and from the 2D folding structure analyses of the 16S rRNA from the type species of the genera investigated demonstrated the diagnostic power of this RNA molecule to reveal the systematics of four genera belonging to the family Myrrhinidae (Gastropoda, Heterobranchia). The "molecular morphological" approach to the 16S rRNA revealed to be a powerful tool to delimit at both species and genus taxonomic levels and to be a useful way of recovering information that is usually lost in phylogenetic analyses. While the validity of the genera Godiva, Hermissenda and Phyllodesmium are confirmed, a new genus is necessary and introduced for Dondice banyulensis, Nemesis gen. nov. and the monospecific genus Nanuca is here synonymised with Dondice, with Nanuca sebastiani transferred into Dondice as Dondice sebastiani comb. nov.
\end{abstract}

Keywords: 2D RNA-Barcoding; molecular morphology; Nudibranchia; Dondice

\section{Introduction}

The use of molecular techniques to investigate the evolutionary history of animal groups and to define monophyletic lineages expanded exponentially in the last few decades, becoming one of the essential steps to accomplish a good integrative taxonomy. To increase the robustness of the obtained results, the integration of different kinds of informative characters has led to an exhaustive search for characters that could be diagnostic at different taxonomic levels. Integrative taxonomy applied to marine Heterobranchia is proving to be a fruitful field of study. In fact, in the last few years, many papers have been published, which included information derived from several biological points of view, including morphological, molecular, chemical, ecological and behavioural characters [1-7]. Regarding the molecular approach, there is a continuous search in the genome for new informative DNA coding and non-coding regions, consequentially resulting in molecules such as proteins and RNA [7-9]. Mitochondrial DNA (mtDNA) is currently, in the greatest number of cases, the most powerful genome being exploited to shed light on lower taxonomic levels, 
such as species and genera, and it remains the most used DNA molecule to delimit species and investigate cryptic diversity and recent speciation events [7,10-12]. In fact, animal mitochondrial DNA is characterised by a high copy number, largely maternal inheritance, lack of recombination, and displays a higher mutation rate than the nuclear DNA. It is affected by some constraints including retention of ancestral polymorphism, male-biased gene flow, selection on any mtDNA nucleotide, introgression following hybridisation and paralogy resulting from transfer of mtDNA gene copies to the nucleus [13-16]. To avoid these pitfalls, nuclear markers are usually added to the molecular analyses. This approach has been applied to marine Heterobranchia (Mollusca, Gastropoda) whose evolutionary history, when studied at family level, is reconstructed using mainly three molecular markers, the two mitochondrial genes, part of Cytochrome oxidase subunit I (COI) and part of the ribosomal subunit $16 \mathrm{~S}$ (16S), as well as the nuclear gene histone 3 (H3) which is well known to be poorly or not quite informative at lower taxonomic levels $[7,17,18]$. By means of these markers, the systematics of several heterobranchs families has been clarified and erroneous outcomes derived from previous morphological studies have been resolved and corrected $[2,3,5]$.

However, the potential of some aspects of the known mitochondrial genome are still incompletely exploited today. These include ribosomal RNA genes, which are transcribed into rRNA molecules able to fold into secondary/tertiary structures that are necessary for correct mitoribosome assembly [19]. The primary sequence of some regions of the mitochondrial rRNA is hypervariable and difficult to align among related species. This rRNA hypervariability occurs in the mitochondrial ribosomal 16S RNA (16S rRNA), used as a classical marker, which folds into different domains and stem-loops. When alignments based on the primary sequences are not easy to achieve, it is a common and suggested practice to remove these portions to stabilise the phylogenetic signal (there are specific programs that help to cut these hypervariable regions, for example the GBlocks program [20,21]). The removal of these unreliable alignment regions from the dataset is promoted by several influential works aimed to demonstrate the improvement of statistical support of the phylogenetic analyses when randomness in sequence alignments is cut out [21-23]. However, this practice means that, unavoidably, very informative regions are often not taken into consideration.

In the last few decades, the comparison of the secondary (2D) structure information of RNA molecules, such as the nuclear ribosomal RNA internal transcribed spacer 2 (ITS2 rRNA) in molluscs (bivalves), has been revealed as a promising approach in both phylogenetic reconstruction and species diagnosis [24-27]. In particular, an important character that has proved very useful are Compensatory Base Changes, CBCs, that are defined as two mutations that occur in a paired region of a primary RNA transcript so that pairing itself is maintained (e.g., G-C mutates to A-U) [28]. On the contrary, information derived from the folded structure of the 16S rRNA has not been utilised in molluscan groups, except for two works by Furfaro et al. [18,29], who analysed this barcoding marker in a couple of sympatric sibling sea slugs (gastropods). These authors reported 2D structural diversity of the $16 \mathrm{~S}$ rRNA, mainly utilising the highly variable L7 and L13 stem-loops [30], demonstrating that secondary RNA structure information is a valuable additional diagnostic tool for integrative taxonomy and species delimitation [18,29].

In this study, we have extended the approach of 2D RNA-barcoding, investigating systematics at a taxonomic level higher than the species level. In particular, it was used as a case study in a polyphyletic clade [31] composed of four genera ranked in the family Myrrhinidae Bergh, 1905: Dondice Marcus Er. 1958; Godiva Macnae, 1954; Hermissenda Bergh, 1879 and Phyllodesmium Ehrenberg, 1831. To date, these genera include four accepted species for Dondice and Godiva respectively, three for Hermissenda and 27 accepted species for Phyllodesmium, which is the Myrrhinid genus that is richest in species. These Myrrhinid genera were previously considered part of the polyphyletic family Facelinidae, but were recently moved to the family Myrrhinidae by Martynov et al. [32], based on phylogenetic evidence from a systematic study focused on other families (i.e., Tergipedidae). 
To date, phylogenetic relationships among these genera and the included species are still incompletely resolved. In fact, there was evidence that the genus Dondice as traditionally conceived is not monophyletic and needs an in-depth study based on a wider dataset [31,32]. The family Myrrhinidae includes charismatic species, which is distributed worldwide and interesting from different points of view. Hermissenda crassicornis (Eschscholtz, 1831) is a model organism used in various research fields, such as neurology, ecology, ethology, pharmacology and toxicology [33-39]. Species belonging to the genus Phyllodesmium are a group of highly specialised nudibranchs with sophisticated species-specific mechanisms of mimicry with external body features indistinguishable from their cnidarian hosts and are animal models for several studies on chemistry and cell biology or focused on the mechanisms of the symbiotic relationship with the zooxanthellae living in their digestive gland cells [40-42]. This family was chosen as a case study to investigate the capability of the 2D folding structure analyses to give useful insight on the systematics of this animal group by looking at alternative morphological, yet molecular, features. This choice was due to the peculiarity of the genera involved, their unresolved phylogenetic histories and a unique ecological defensive strategy shown by most of the species involved (i.e., the capability to autotomise their cerata if disturbed [31]).

Suitable in-group and out-group species were selected, and the definitive dataset defined by being able to describe, with statistically supported analyses, the evolutionary history among representatives of the family Myrrhinidae. Particular attention was given to the inclusion of all the type species of the genera considered in the present study. Phylogenetic analyses were performed, based on an enlarged dataset that includes additional related genera, to investigate the evolutionary history of this interesting group of sea slugs. According to the phylogenetic analysis carried out, the 16S rRNA folding structures of all the type species of the genera belonging to the family Myrrhinidae (Dondice occidentalis (Engel, 1925); Hermissenda opalescens (J. G. Cooper, 1863); Godiva quadricolor (Barnard, 1927); Phyllodesmium hyalinum Ehrenberg, 1831] plus Nanuca sebastiani Er. Marcus, 1957, currently ascribed to the Family Facelinidae Bergh, 1889 and of Aeolidiella alderi (Cocks, 1852), A. sanguinea (Norman, 1877) (Aeolidiidae Gray, 1827), Babakina anadoni (Ortea, 1979), B. indopacifica Gosliner, Gonzalez-Duarte \& Cervera, 2007 (Babakinidae Roller, 1973) and Dicata odhneri Schmekel, 1967 (Facelinidae Bergh, 1889)) were examined for comparison. After a stem-loop structure analysis of the $16 \mathrm{~S}$ rRNA molecule, the specific and highly variable L7 stem-loop was chosen as the most divergent and informative for this group and was revealed to be diagnostic to unambiguously discriminate different $16 \mathrm{~S}$ rRNA structures. This approach, based on the description of the "molecular morphology" of this very variable region of the mitochondrial 16S rRNA [18], can be considered as an additional tool for species delimitation and integrative taxonomy in Heterobranchia and more generally in marine molluscs. Considering all these issues, the aims of the present work were to: (1) provide an updated phylogenetic framework for the genera of the family Myrrhinidae; (2) describe for the first time the consensus 2D secondary structure of the genus Dondice; (3) investigate the diagnostic power of the 16S 2D molecular morphology as an additional tool useful for integrative taxonomy and for shedding light on the particularly intricate history of the family Myrrhinidae; (4) introduce Nemesis gen. nov. as a new genus of the family Myrrhinidae; (5) rename the taxon Nanuca sebastiani to Dondice sebastiani comb. nov.

\section{Materials and Methods}

\subsection{Phylogenetic Analyses}

The dataset consisted of 47 sequences, retrieved from GenBank, belonging to 30 species, including the out-group (Table 1). The mitochondrial markers COI and $16 \mathrm{~S}$ and the nuclear marker $\mathrm{H} 3$ are commonly used in nudibranch phylogenetics (e.g., [6,17,43]), the mitochondrial ones being highly variable and informative at a shallow level of divergence, and the nuclear one having a slow rate of mutation, and thus, being more suitable to detect deep divergences in the tree, such as those with a distant out-group. 
Table 1. Species name, collection localities, Voucher IDs and sequence accession numbers (H3: Histone 3; 16S; COI: Cytochrome Oxidase subunit 1) of the specimens analysed.

\begin{tabular}{|c|c|c|c|c|c|}
\hline SPECIES & LOCALITY & VOUCHER & H3 & $16 S$ & COI \\
\hline Aeolidiella alderi (Cocks, 1852) & Italy & ZSMMol20012341 & HQ616795 & HQ616766 & HQ616729 \\
\hline Aeolidiella sanguinea (Norman, 1877) & $\begin{array}{c}\text { France (Atlantic } \\
\text { Ocean) }\end{array}$ & MNCN/ADN51932 & JX087600 & JX087538 & JX087466 \\
\hline Babakina anadoni (Ortea, 1979) & Brazil & MNRJ10893 & HQ616775 & HQ616709 & HQ616746 \\
\hline Babakina anadoni (Ortea, 1979) & Galicia, Spain & MNCN15.05/46704 & HQ616796 & HQ616730 & HQ616767 \\
\hline $\begin{array}{c}\text { Babakina indopacifica Gosliner, } \\
\text { Gonzalez-Duarte \& Cervera, } 2007\end{array}$ & $\begin{array}{l}\text { Luzon, Batangas, } \\
\text { Philippines }\end{array}$ & CASIZ177458 & HM162587 & HM162678 & HM162754 \\
\hline Dicata odhneri Schmekel, 1967 & $\begin{array}{c}\text { Ballanera, } \\
\text { Algesiras, Spain }\end{array}$ & BAU2674 & LT596569 & LT596549 & LT596560 \\
\hline Dicata odhneri Schmekel, 1967 & Andalusia, Spain & MNCN15.05/53692 & & HQ616739 & HQ616773 \\
\hline $\begin{array}{c}\text { Dondice banyulensis Portmann \& } \\
\text { Sandmeier, } 1960\end{array}$ & Djerba, Tunisia & RM3_129 & LS483284 & LS483274 & LS483267 \\
\hline $\begin{array}{c}\text { Dondice banyulensis Portmann \& } \\
\text { Sandmeier, } 1960\end{array}$ & $\begin{array}{l}\text { Argentario, } \\
\text { Tuscany, Italy }\end{array}$ & RM3_356 & LS483285 & LS483275 & LS483268 \\
\hline $\begin{array}{c}\text { Dondice banyulensis Portmann \& } \\
\text { Sandmeier, } 1960\end{array}$ & $\begin{array}{l}\text { Sant'Agostino, } \\
\text { Latium, Italy }\end{array}$ & RM3_290 & LS483286 & LS483276 & LS483269 \\
\hline $\begin{array}{c}\text { Dondice banyulensis Portmann \& } \\
\text { Sandmeier, } 1960\end{array}$ & & Db_60 & & GQ403751 & GQ403773 \\
\hline Dondice occidentalis (Engel, 1925) & Exuma, Bahamas & LACM177715 & KC526529 & KC526510 & \\
\hline Dondice occidentalis (Engel, 1925) & & LACM2003-41.5 & JQ699394 & JQ699482 & JQ699570 \\
\hline Dondice occidentalis (Engel, 1925) & Exuma, Bahamas & D252 & KC526527 & KC526518 & \\
\hline Dondice occidentalis (Engel, 1925) & Jamaica & JG61 & KC526534 & KC526512 & \\
\hline $\begin{array}{c}\text { Dondice parguerensis Brandon \& } \\
\text { Cutress, } 1985\end{array}$ & $\begin{array}{l}\text { La Parguera, } \\
\text { Puerto Rico }\end{array}$ & LACM177705 & KC526535 & KC526520 & \\
\hline $\begin{array}{c}\text { Dondice trainitoi Furfaro \& } \\
\text { Mariottini, } 2020\end{array}$ & $\begin{array}{l}\text { Civitavecchia, } \\
\text { Latium, Italy }\end{array}$ & RM3_425 & LS483287 & LS483277 & LS483270 \\
\hline $\begin{array}{c}\text { Dondice trainitoi Furfaro \& } \\
\text { Mariottini, } 2020\end{array}$ & $\begin{array}{l}\text { Civitavecchia, } \\
\text { Latium, Italy }\end{array}$ & RM3_596 & LS483288 & LS483278 & LS483271 \\
\hline Godiva quadricolor (Barnard, 1927) & $\begin{array}{l}\text { Sabaudia, Latium, } \\
\text { Italy }\end{array}$ & RM3_117 & LS483289 & LS483279 & MG546001 \\
\hline Godiva quadricolor (Barnard, 1927) & $\begin{array}{l}\text { Sabaudia, Latium, } \\
\text { Italy }\end{array}$ & RM3_153 & LS483290 & LS483280 & MG546002 \\
\hline Godiva quadricolor (Barnard, 1927) & $\begin{array}{l}\text { Sabaudia, Latium, } \\
\text { Italy }\end{array}$ & RM3_154 & LS483291 & LS483281 & MG546003 \\
\hline Godiva quadricolor (Barnard, 1927) & $\begin{array}{l}\text { Knysna Lagoon, } \\
\text { South Africa }\end{array}$ & CASIZ176385 & HM162589 & HM162680 & HM162756 \\
\hline Hermissenda opalescens & $\begin{array}{c}\text { Monterey Bay, CA, } \\
\text { USA }\end{array}$ & isolate_TL270 & KU950225 & KU950130 & KU950196 \\
\hline Hermissenda opalescens & Malibu, CA, USA & isolate_TL275 & KU950224 & KU950129 & KU950195 \\
\hline Hermissenda opalescens & $\begin{array}{l}\text { Long Beach, CA, } \\
\text { USA }\end{array}$ & isolate_TL269 & KU950222 & KU950128 & KU950193 \\
\hline Hermissenda emurai & $\begin{array}{l}\text { Tateyama-Chiba, } \\
\text { Japan }\end{array}$ & isolate_TL185 & KU950215 & KU950123 & KU950186 \\
\hline Hermissenda emurai & $\begin{array}{l}\text { Tateyama-Chiba, } \\
\text { Japan }\end{array}$ & isolate_TL184 & KU950214 & KU950122 & KU950185 \\
\hline Hermissenda crassicornis & $\begin{array}{l}\text { Victoria, B.C., } \\
\text { Canada }\end{array}$ & isolate_TL200 & KU950210 & KU950118 & KU950174 \\
\hline Hermissenda crassicornis & $\begin{array}{l}\text { Victoria, B.C., } \\
\text { Canada }\end{array}$ & isolate_TL204 & KU950212 & KU950121 & KU950178 \\
\hline Nanuca sebastiani & & & JQ699469 & JQ699557 & JQ699633 \\
\hline $\begin{array}{c}\text { Phyllodesmium briareum (Bergh, } \\
\text { 1896) }\end{array}$ & $\begin{array}{l}\text { Batangas, } \\
\text { Philippines }\end{array}$ & CASIZ 177239 & HQ010460 & HQ010528 & HQ010492 \\
\hline $\begin{array}{c}\text { Phyllodesmium colemani Rudman, } \\
1991\end{array}$ & $\begin{array}{l}\text { Batangas, } \\
\text { Philippines }\end{array}$ & CASIZ 177647 & HQ010466 & HQ010534 & HQ010498 \\
\hline $\begin{array}{c}\text { Phyllodesmium crypticum Rudman, } \\
1981\end{array}$ & $\begin{array}{l}\text { Batangas, } \\
\text { Philippines }\end{array}$ & CASIZ 180381 & HQ010477 & HQ010543 & HQ010507 \\
\hline
\end{tabular}


Table 1. Cont.

\begin{tabular}{|c|c|c|c|c|c|}
\hline SPECIES & LOCALITY & VOUCHER & H3 & $16 S$ & $\mathrm{COI}$ \\
\hline $\begin{array}{c}\text { Phyllodesmium horridum (Macnae, } \\
\text { 1954) }\end{array}$ & $\begin{array}{l}\text { Cape Region, } \\
\text { South Africa }\end{array}$ & CASIZ176127 & HM162590 & HM162681 & HM162757 \\
\hline $\begin{array}{l}\text { Phyllodesmium hyalinum Ehrenberg, } \\
1831\end{array}$ & & Phy.orig. & & GQ403756 & GQ403778 \\
\hline $\begin{array}{c}\text { Phyllodesmium jakobsenae Burghardt } \\
\text { \& Wägele, } 2004\end{array}$ & $\begin{array}{l}\text { Batangas, } \\
\text { Philippines }\end{array}$ & CASIZ 177576 & HQ010456 & HQ010524 & HQ010489 \\
\hline $\begin{array}{c}\text { Phyllodesmium karenae Moore \& } \\
\text { Gosliner, } 2009\end{array}$ & $\begin{array}{l}\text { Batangas, } \\
\text { Philippines }\end{array}$ & CASIZ 180384 & HQ010478 & HQ010544 & HQ010508 \\
\hline $\begin{array}{l}\text { Phyllodesmium koehleri Burghardt, } \\
\text { Schrödl \& Wägele, } 2008\end{array}$ & $\begin{array}{l}\text { Batangas, } \\
\text { Philippines }\end{array}$ & CASIZ 177693 & HQ010462 & HQ010530 & HQ010494 \\
\hline $\begin{array}{c}\text { Phyllodesmium lizardensis Burghardt, } \\
\text { Schrödl \& Wägele, } 2008\end{array}$ & $\begin{array}{l}\text { Batangas, } \\
\text { Philippines }\end{array}$ & CASIZ 180382 & HQ010474 & HQ010540 & HQ010505 \\
\hline $\begin{array}{c}\text { Phyllodesmium macphersonae (Burn, } \\
\text { 1962) }\end{array}$ & $\begin{array}{l}\text { Batangas, } \\
\text { Philippines }\end{array}$ & CASIZ 177493 & HQ010453 & HQ010522 & HQ010487 \\
\hline $\begin{array}{c}\text { Phyllodesmium opalescens Rudman, } \\
1991\end{array}$ & $\begin{array}{l}\text { Batangas, } \\
\text { Philippines }\end{array}$ & CASIZ 177541 & HQ010450 & HQ010519 & HQ010485 \\
\hline $\begin{array}{c}\text { Phyllodesmium parangatum Ortiz \& } \\
\text { Gosliner, } 2003\end{array}$ & $\begin{array}{l}\text { Batangas, } \\
\text { Philippines }\end{array}$ & CASIZ 180383B & HQ010476 & HQ010542 & HQ010506 \\
\hline $\begin{array}{c}\text { Phyllodesmium poindimiei (Risbec, } \\
\text { 1928) }\end{array}$ & $\begin{array}{l}\text { Batangas, } \\
\text { Philippines }\end{array}$ & CASIZ 177783 & HQ010463 & HQ010531 & HQ010495 \\
\hline $\begin{array}{l}\text { Phyllodesmium rudmani Burghardt \& } \\
\text { Gosliner, } 2006\end{array}$ & $\begin{array}{l}\text { Batangas, } \\
\text { Philippines }\end{array}$ & CASIZ 177622 & HQ010461 & HQ010529 & HQ010493 \\
\hline $\begin{array}{l}\text { Phyllodesmium tuberculatum Moore } \\
\text { \& Gosliner, } 2009\end{array}$ & $\begin{array}{l}\text { Batangas, } \\
\text { Philippines }\end{array}$ & CASIZ 177663 & HQ010465 & HQ010533 & HQ010497 \\
\hline Duvaucelia striata Haefelfinger, 1963 & $\begin{array}{l}\text { Giannutri Is., } \\
\text { Tuscany, Italy }\end{array}$ & BAU2695 & LT615407 & LT596542 & LT596540 \\
\hline Duvaucelia striata Haefelfinger, 1963 & $\begin{array}{l}\text { Formiche Is., } \\
\text { Tuscany, Italy }\end{array}$ & BAU2696 & LT615408 & LT596543 & LT596541 \\
\hline
\end{tabular}

The selected sequences (Table 1) were aligned using the Muscle algorithm implemented in MEGA 6.0 [44]. The Gblocks $0.91 \mathrm{~b}$ web server [20,21] was used to remove the hyper-divergent regions of the $16 \mathrm{~S}$ rDNA alignment, using the less stringent parameter setting. For each gene alignment the best evolutionary model was selected by JModelTest 0.1 [45] according to the Bayesian Information Criterion (BIC).

Downstream phylogenetic analyses were performed on the single 16S dataset and on the concatenated and partitioned dataset. Phylogenetic analyses were performed using Bayesian Inference (BI) and Maximum Likelihood (ML) methods. Duvaucelia striata Haefelfinger, 1963 was used as the out-group in BI and ML phylogenetic analyses based on previous tests aimed to find the best in-group and out-group. BI analyses were carried out with MrBayes 3.2.6 [46], implementing the models selected by JModel Test for each gene partition. We ran four Markov-chains of five million generations each, sampled every 1000 generations. Consensus trees were calculated on trees sampled after a burn-in of $25 \%$. MCMC chain convergence was verified by average standard deviation of split frequencies values below 0.006 and confirmed in Tracer 1.7 [47]. Maximum Likelihood analyses were performed in raxmlGUI 1.5b2 [48], a graphical front end for RAxML 8.2.1 [49], with 100 independent ML searches and 1000 bootstrap replicates (command "- $f$ b"), applying the general time-reversible model with a gamma model of rate heterogeneity (GTRGAMMA), with individual gene partitions.

\subsection{RNA Secondary Structure Modelling and Compensatory Base Changes (CBCs)}

Partial 16S rRNA (sequence region from L7 to L13 stem-loops) secondary structure was obtained using the program "The Mfold web server" [50,51]. The best-supported folding models were predicted combining a thermodynamic approach [52] with a close study of the paired conserved regions and the identification of CBCs and semi-CBCs. 


\subsection{Morphological Analyses}

To provide additional morphological data that were missing in the original description of Dondice banyulensis, anatomical analyses of the radula and jaws from two individuals of $D$. banyulensis were carried out. Buccal masses were removed and dissolved in a Proteinase K solution for the extraction of the chitinous structures. Radulae and jaws were rinsed in water, dried and mounted for examination by optical microscopy. The buccal structures were then mounted and gold coated in an Emitech K550 unit for SEM analysis. To obtain high resolution pictures, SEM images at different magnification levels were performed using the JSM-6480LV Scanning Electron Microscope (JEOL Ltd., Tokyo, Japan) at the Laboratorio di Microscopia Elettronica, Department of Mathematics and Physics, University of Salento. Analyses of the reproductive system of $D$. banyulensis were carried out by anatomical dissection under a stereomicroscope.

\section{Results}

\subsection{Phylogenetic Analyses}

The definitive dataset consisted of 134 sequences from 47 specimens belonging to 30 different species, including the out-group (Figure 1, Table 1). The single $16 \mathrm{~S}$ dataset consisted of 350 nucleotides, while the final concatenated alignment was 1232 nucleotides long. The best evolutionary models selected by JModelTest 0.1 according to the Bayesian Information Criterion (BIC) were: TIM1 + I + G, HKY + I + G and TIM2ef + G for the COI, $16 \mathrm{~S}$ and H3 alignments, respectively. Results from Bayesian and Maximum Likelihood analyses yielded congruent topologies (Figure 1) both grouping all the Phyllodesmium species in a single and strongly supported $(\mathrm{BI}=1 ; \mathrm{ML}=100)$ monophyletic clade, sister to Godiva quadricolor $(\mathrm{BI}=1 ; \mathrm{ML}=100)$ with a low statistical support $(\mathrm{BI}=75 ; \mathrm{ML}=45)$. These two clades are sister to another monophyletic group $(B I=1 ; M L=81)$, which includes one monophyletic clade $(\mathrm{BI}=1 ; \mathrm{ML}=100)$ that grouped species such as Dondice occidentalis and $D$. parguerensis $(\mathrm{BI}=0.99 ; \mathrm{ML}=100)$ and $D$. trainitoi $(\mathrm{BI}=1 ; \mathrm{ML}=97)$ sister to Nanuca sebastiani $(\mathrm{BI}=1 ; \mathrm{ML}=100)$, and another monophyletic clade, which includes all the species belonging to the genus Hermissenda $(\mathrm{BI}=1 ; \mathrm{ML}=100)$. Dondice banyulensis is the sister to all this big monophyletic clade $(\mathrm{BI}=0.91 ; \mathrm{ML}=70)$, with strong statistical support $(\mathrm{BI}=1$; $\mathrm{ML}=100)$. The two Aeolidiella sister species $(\mathrm{BI}=1 ; \mathrm{ML}=100)$ are sister to all the previously reported clades forming a large monophyletic group $(B I=0.99 ; M L=69)$. The latter group is sister to Babakina spp. ( $\mathrm{BI}=73 ; \mathrm{ML}=56)$ with Dicata odhneri $(\mathrm{BI}=1 ; \mathrm{ML}=100)$ basal to all the previously reported clades and with the out-group Duvaucelia striata as the basal sister group to all the mentioned species. BI and ML analyses of the single 16S dataset yielded congruent results but with low statistical support (Figure S1).

\section{2. $16 S$ RNA Primary and Secondary Structures Analysis}

The mitochondrial $16 \mathrm{~S}$ rRNA multiple sequence alignments were performed simultaneously considering the secondary structure of each sequence to obtain the optimisation of the final alignment. The $16 \mathrm{~S}$ rRNA single gene alignment consisted of 407 positions and 47 sequences, obtained from 30 species belonging to 9 accepted genera, including the outgroup (Table 1). We have analysed the secondary structure (2D) of the $3^{\prime}$ half portion of the $16 \mathrm{~S}$ rRNA gene, corresponding to the $\mathrm{V}$ domain and including the L7-L13 stem-loops $[30,53]$ (Figure S3), in order to highlight the different diagnostic nucleotides characterising genus and species [54]. No variability in the folding 2D structures was detected within the same species. As expected, the $\mathrm{V}$ domain showed a high conservation of the primary sequence and global folding when compared among the species analysed (Table 1), which conforms to the canonical molluscan architecture $[18,24,25,29,30,53]$. Among the variable stem-loops, the L7 was the most divergent rRNA sequence containing diagnostic nucleotides and it was taken into consideration as an RNA barcoding region [18,29]. In Figure 2, the folding models of the $16 \mathrm{~S}$ rRNA V domain are displayed of eight representative species belonging to seven genera. The L7 stem-loops analysed range from 14 (G. quadricolor) to 23 (B. anadoni) nucleotides (nt) in length and share a high homology of the sequence/2D structure among 
three Dondice spp. (i.e., D. occidentalis, D. parguerensis and D. trainitoi) and the monotypic $N$. sebastiani (Figure 3). As shown in Figure 3, the stem-loop is composed of 19 nucleotides in these taxa, the stem composed of five base pairs is identical, while the nine nt long loop shows six identical and three variable nucleotides. Unexpectedly, the L7 stem-loop of Dondice banyulensis revealed to be not correlated to the one of the congeneric species when considering both the primary sequence and 2D structure, exhibiting no significant folding homology (Figure 3). Moreover, in Figure 3 the L7 stem-loops of H. opalescens, G. quadricolor, P. hyalinum, A. alderi and B. anadoni are depicted for comparison. The secondary structure of the H. opalescens L7 stem-loop, chosen as an example of the genus Hermissenda since it is the type species of the genus, reveals a close homology in sequence/folding with the ones of D. occidentalis and N. sebastiani, which are the type species of Dondice and Nanuca genera, respectively; the nucleotide sequence of the shorter stem in particular is identical, while the eight nucleotides-long loop shares six identical nucleotides (Figure 3). Interestingly, two groups of nucleotide positions can be observed in the L7 stem-loop of the members grouped in the Dondice clade, which is formed by three taxa (Figure 3 and Figure S4): the first, variable and diagnostic for species identification and the second conserved and diagnostic at the genus level. Three diagnostic nucleotide substitutions separate Dondice spp. and the closely related Nanuca taxon, indicating that the latter monotypic genus is strongly related to Dondice. On the other hand, four nucleotide positions are conserved and shared in the clade which includes both genera Dondice and Nanuca. Taking into account the folding models of the L8-11 stem-loops, the 2D structures of these hairpins revealed a closer homology between D. occidentalis and N. sebastiani (Figure S3) than with D. banyulensis. In Figure S3, the L8-11 stem-loops are circled to show both the 2D structure and the nucleotides differences occurring among the three taxa. In particular, despite the dissimilar loop size of the L10 stem-loop, due to a single mismatch in the stem, $D$. occidentalis and N. sebastiani share a higher 2D folding homology than with D. banyulensis. Regarding the type species of the Godiva genus, the G. quadricolor L7 stem-loop is slightly divergent in sequence and 2D structure, but still exhibiting five identical nucleotides in its 10 nucleotides-long loop. The folding homology decreases analysing the 2D structures of the L7 stem-loop of P. hyalinum, a species type of the genus Phyllodesmium (four identical nucleotide in the $12 \mathrm{nt}$ long stem). Two other examples of the L7 stem-loop refer to A. alderi and $B$. anadoni, which both show very divergent $2 \mathrm{D}$ structures.

To summarise, the L7 stem-loop of D. banyulensis revealed to be the more divergent 2D structure compared to the ones of Dondice spp., N. sebastiani, H. opalescens, G. quadricolor and P. hyalinum, exhibiting no significant folding homology (Figure 3 and Figure S4). According to both phylogenetic and 16S rRNA 2D structure analyses, the monotypic genus Nanuca must be synonymised with Dondice, and consequently, the taxon Nanuca sebastiani can be renamed to Dondice sebastiani comb. nov.

\subsection{Morphological Analyses}

Morphological analyses of the buccal apparatus from two specimens (Vouchers RM3_290 and RM3_311) belonging to Dondice banyulensis (Figure 4) are shown in Figure 5. The high-resolution SEM pictures obtained showed that features of the jaws and radula are congruent with drawings reported in the original description [55]. The reproductive system was examined and the resulted drawing congruent with the one reported from the holotype (Figure S2). 


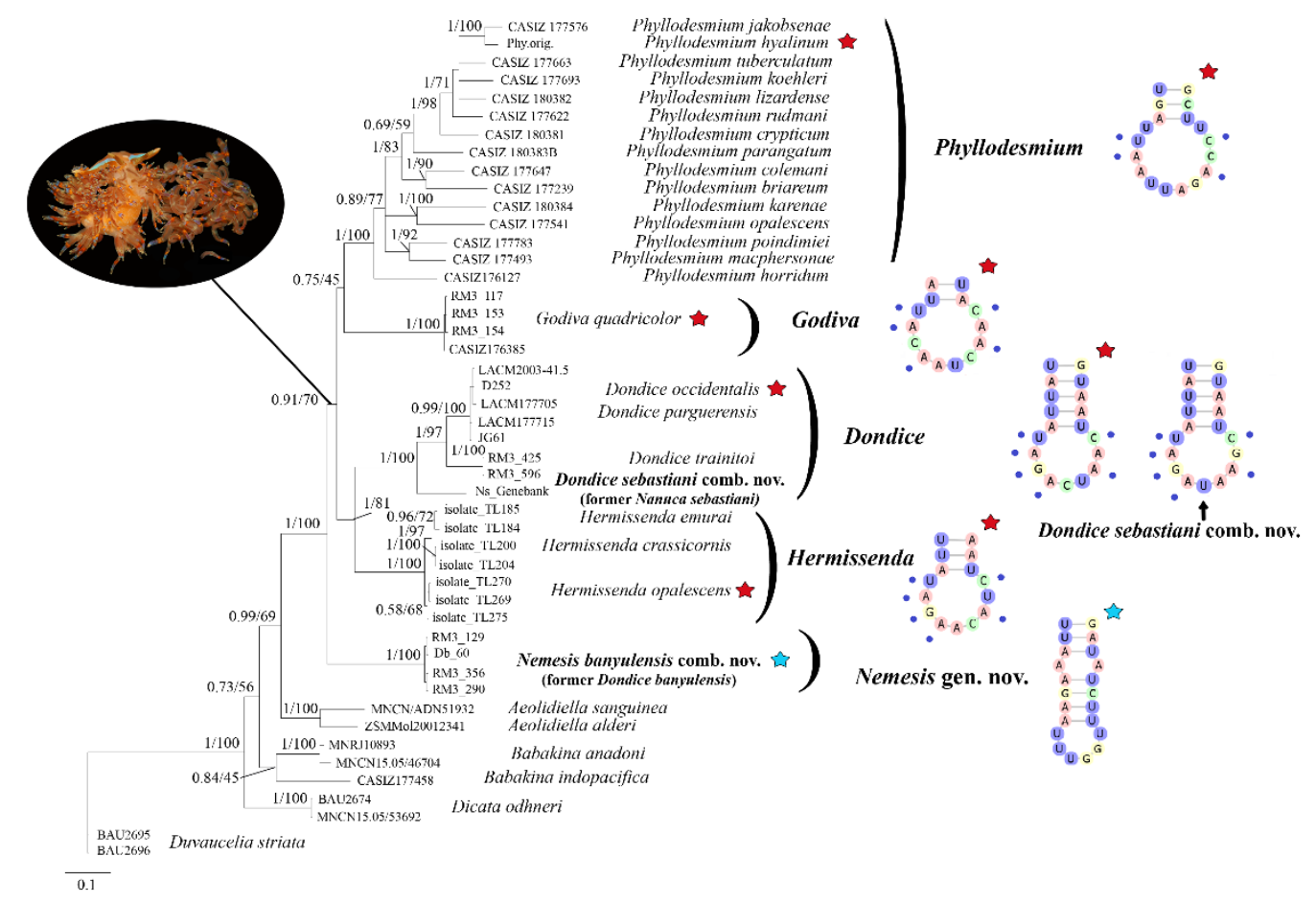

Figure 1. Bayesian phylogenetic tree based on the concatenated dataset (H3, 16S, COI). Bayesian posterior probability (left) and Bootstrap (right) values are indicated at each node. Red stars highlight the type species of the genera analysed and the relative 16S 2D L7 structures. The blue stars refer to the type species of the Nemesis gen. nov. and its 16S rRNA 2D L7 structure. In the black oval at the top left, G. quadricolor is shown as well as the autotomy of its cerata as the defensive strategy characteristic and common to the monophyletic group which includes Dondice, Godiva, Hermissenda and Phyllodesmium.
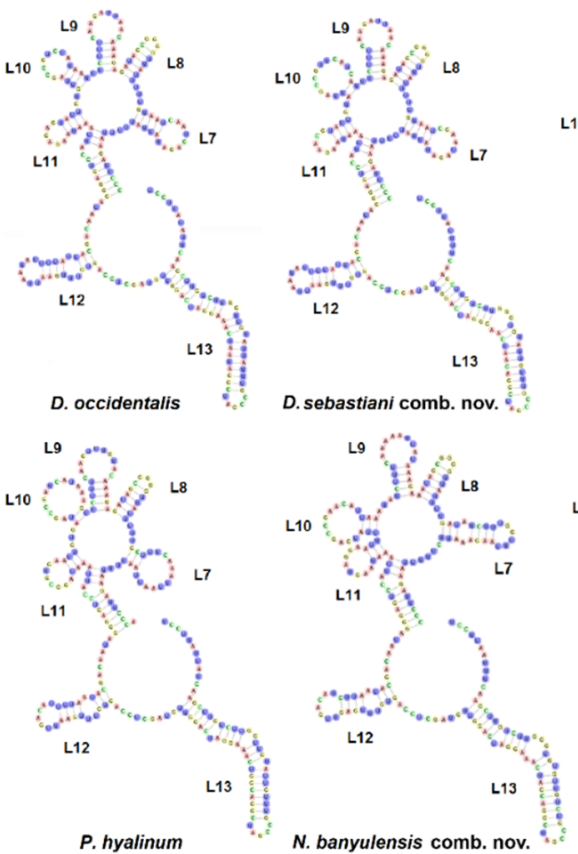
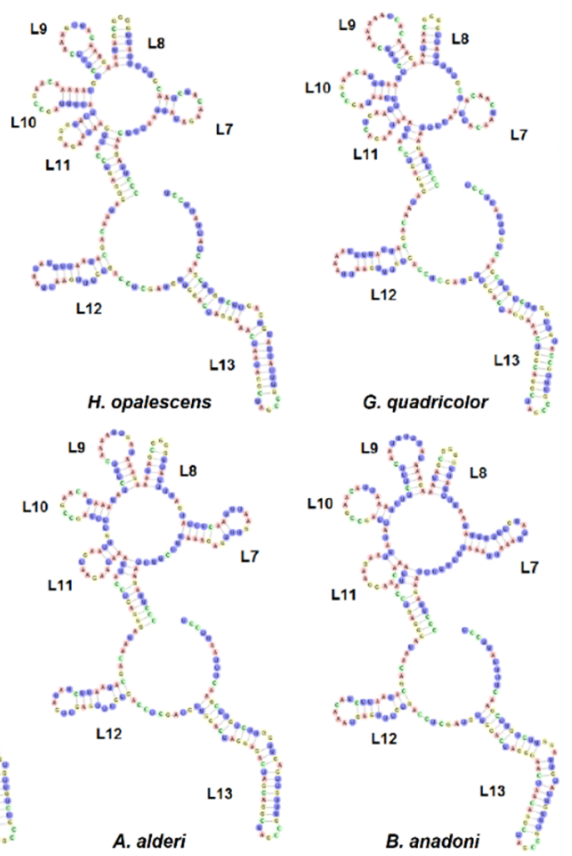

Figure 2. Folding models of the $16 \mathrm{~S}$ rRNA V domain of the representative species analysed in the present work. 
a
D. occidentalis
D. sebastiani comb. nov.
H. opalescens
G. quadricolor
$P$. hyalinum
N. banyulensis comb. nov.
A. alderi
B. anadoni

UAUUAUAGACUAAC----UAAUG

UAUUAUAGAUAAGC----UAAUG

--UUAUAGAACAUC----UAA--

-AUU-ACAAUCAAC-----AU--

-GAU-UAAUUAGAC----CUU--

UUAAAGAAUUUGGU-UUCUAUAG

UAAAUUAAAUUAUGUUU--UUUA

UAAAGAGUUUGAAUUUAACUUUA

b
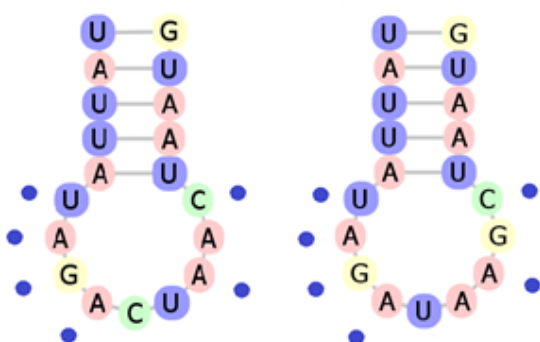

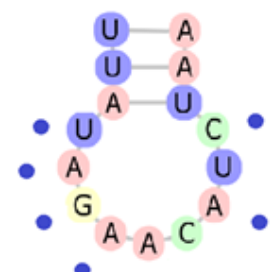

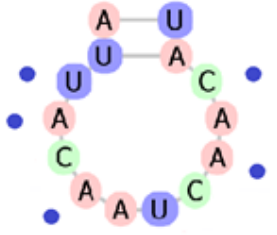

G. quadricolor
D. occidentalis

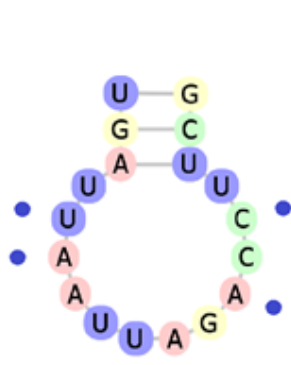

D. sebastiani comb. nov.

$$
\text { U- G }
$$$$
\text { U - A }
$$

$$
\begin{aligned}
& A^{A} \quad \text { A } \\
& \text { A } A \\
& \text { G }-C \\
& \text { A - U } \\
& U^{A} U \\
& \text { U } \mathrm{G}^{\mathrm{G}}
\end{aligned}
$$

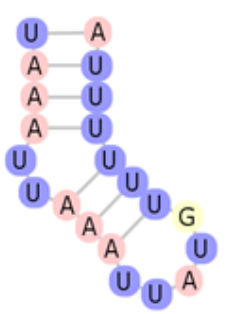

A. alderi

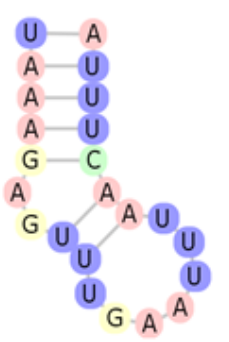

B. anadoni

Figure 3. L7 stem-loops of the species here analysed. (a) Primary sequence alignment of the L7 stem-loops among the species analysed in the present work. (b) Blue circles indicate the conserved nucleotide positions in Dondice, Nanuca, Hermissenda, Godiva and Phyllodesmium genera. 


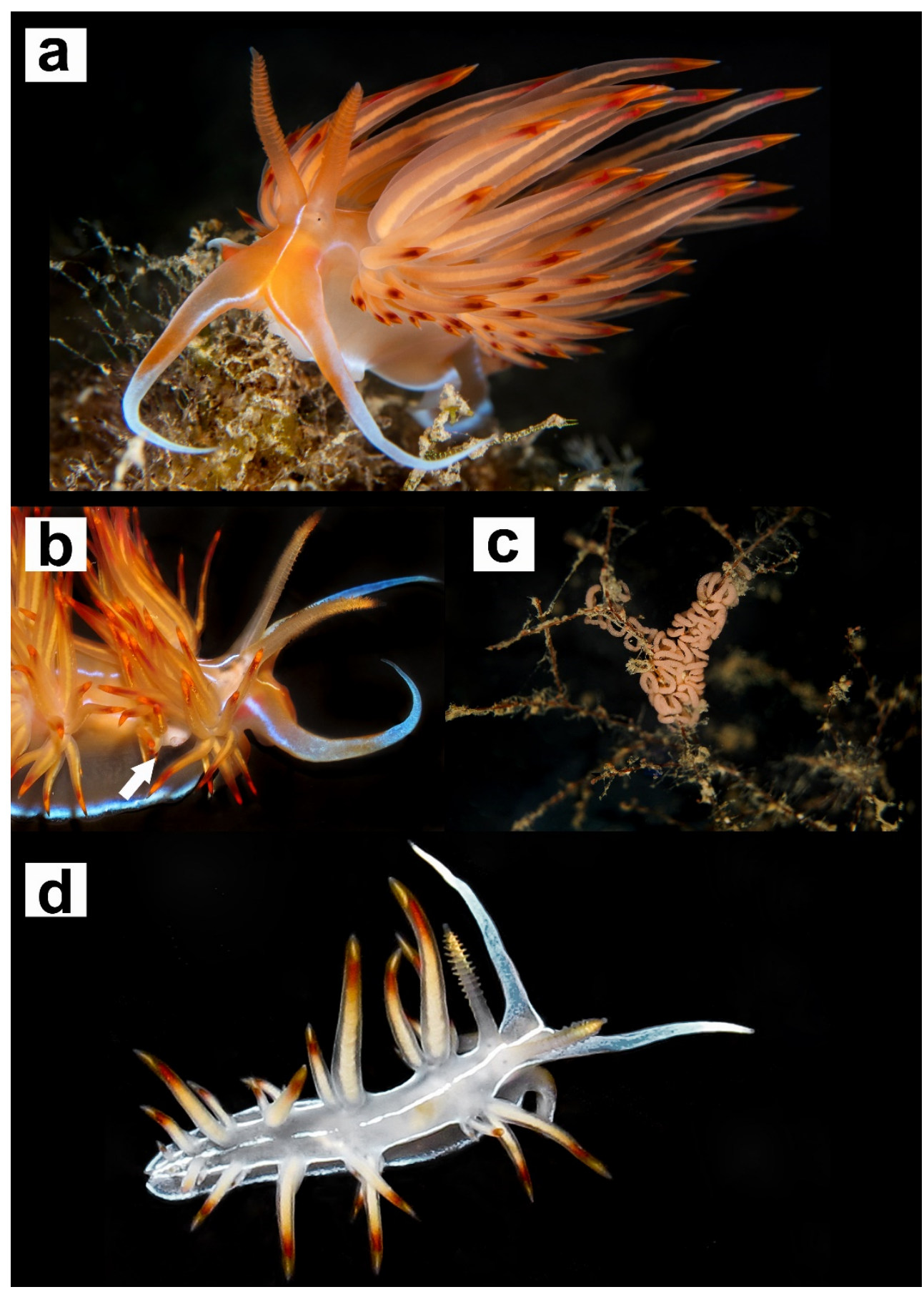

Figure 4. Images of individuals belonging to Nemesis banyulensis comb. nov. (original name Dondice banyulensis) (a,b,d) and the typical egg ribbon (c) of the species. (a) Adult specimen from the 'Peschereccio' wreck, Gallipoli, Apulia (Central Tyrrhenian Sea, Mediterranean Sea). (b) Particular of the anterior right portion of one specimen from 'Asia' wreck in Civitavecchia (Central Tyrrhenian Sea, Mediterranean Sea) and its reproductive openings highlighted with a white arrow. (c) The typical orange to pinkish egg ribbon lead on a hydroid colony in Sant' Agostino, Civitavecchia (Central Tyrrhenian Sea, Mediterranean Sea). (d) Picture of a juvenile individual from Scilla in Calabria (South Tyrrhenian Sea, Mediterranean Sea) showing the difference in the chromatic pattern from young to adult individuals. 


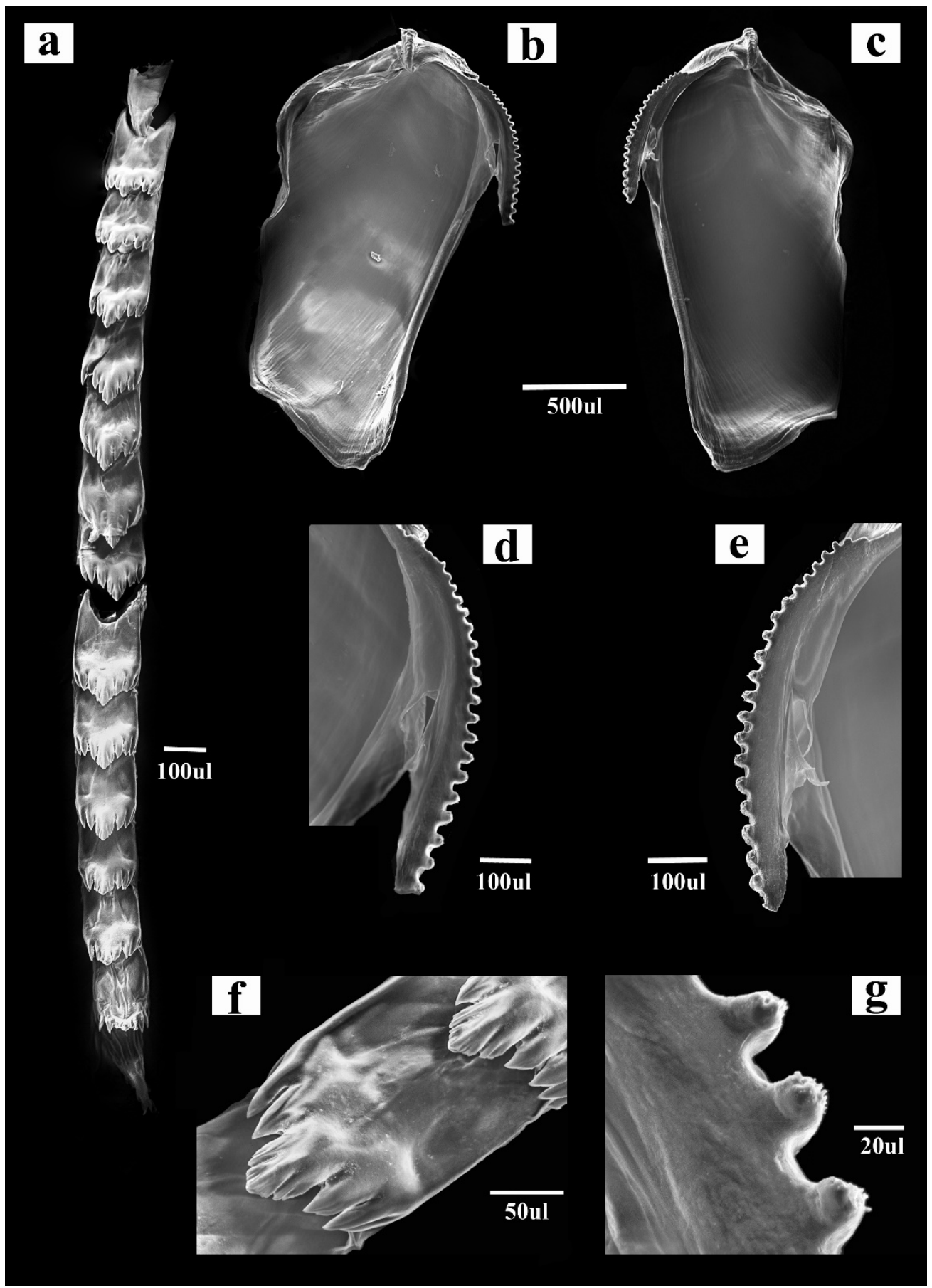

Figure 5. SEM images of the jaws and radula of Nemesis banyulensis comb. nov. (former Dondice banyulensis) (voucher RM3_290) (a), the entire radula of (b,c) both the left (b) and the right (c) jaws (d,e) particular of the masticatory boarders of the jaws. (f) Detail of the tooth of the radula with the cusp and the lateral denticles clearly visible. (g) The denticulated denticles of the masticatory border of the jaws at a high magnification level.

\section{Discussion}

Based on these results, Dondice banyulensis clearly represents an independent lineage from the species of Dondice s.s. and deserves a genus on its own.

Taxonomy

Family Myrrhinidae Bergh, 1905

Nemesis gen. nov.

urn:lsid:zoobank.org:act:8F4E1E1D-6E8A-41CB-81FA-487A58829C65 
Figures 4 and 5 and Figure S1

Type species. Dondice banyulensis Portmann \& Sandmeier, 1960

Etymology. The genus name was chosen to recall the Greek goddess Nemesis and her sense of justice to allocate the former D. banyulensis in the appropriate genus.

Diagnosis. Myrrhinid with rhinophores annulate and produced anterior foot corners. It has jaws with a single row of denticles that can be denticulated in their apical part. The central cusp of the radular tooth is not marked and is a little longer than lateral denticles. The large stomach, followed by a short smooth intestine, terminates with the anus, which is cleioproct and located inside the second group of cerata on the right side of the body. The long distal and proximal deferent ducts of the male portion of the reproductive system terminates with the unarmed penis. It is not able to autotomise the cerata when stressed by possible predators.

Species included. Nemesis banyulensis (Portmann \& Sandmeier, 1960), comb. nov. (Original description in [55]; additional data in Figures 4 and 5 and Figure S2).

Remarks. The new genus is diagnosed by a radular tooth characterised by the cuspid that is slightly marked and a little longer than lateral denticles compared to Dondice s.s., Godiva and Phyllodesmium and by the more elongated distal and proximal male deferent ducts of the reproductive system compared to Dondice s.s., Godiva and Phyllodesmium.

Mitochondrial DNA is, to date, the most powerful DNA molecule able to discriminate at species and genus taxonomic levels and is necessary to carry out any integrative systematic study [15,56-60]. In fact, even if today a lot of work is being done to find markers that are alternative to and independent from mitochondrial DNA, such as nuclear markers, it is undeniable that mitochondrial DNA is currently the most informative at lower taxonomic levels. Evidence for this is that nowadays there are two markers that are commonly used in most of the nudibranch systematic studies: the mitochondrial COI and the 16S. While waiting to find useful nuclear alternatives for the study of the evolutionary relationships that occurred between highly related groups, it may be useful to improve and optimise the study of the currently available markers, especially if these have characteristics that are potentially very useful; however, little is known of these characteristics in nudibranchs. One of these features is the ability of the $16 \mathrm{~S}$ rRNA to fold into a 2D structure, which is mandatory for correct mitoribosome assembly [19]. In the mitochondrial 16S rRNA molecule, the $\mathrm{V}$ domain includes the L7-L13 stem-loops [30,53] that can be used to search for diagnostic nucleotides [54]. The 2D structure analysis using the 16S rRNA in molluscs has revealed to be capable to discriminate a couple of sympatric sibling sea slugs [18,29]. In particular, the stem-loop L9 nucleotide analyses confirmed the separation of the species Diaphorodoris alba Portmann \& Sandmeier, 1960 and D. luteocincta (M. Sars, 1870), revealing some diagnostic nucleotides producing a 2D structural diversity [18]. Moreover, the L7 and L13 stem-loops resulted to be diagnostic in separating the two sibling Mediterranean species Caloria elegans (Alder and Hancock, 1845) and Facelina quatrefagesi (Vayssière, 1888) [29].

The case of the family Myrrhinidae is particularly intriguing due to the importance of the charismatic species included and because the genera belonging to this family were the object of recent integrative taxonomic studies, which, however, could not resolve important aspect of their systematics [31,32]. The latter studies have highlighted the possible polyphyletic nature of the Myrrhinidae genera that invoked more in-depth studies to resolve open questions. For this reason, in the present work, a broad dataset, including more individuals and species, was investigated using another, until now poorly known, source of information: the 2D structure of the $16 \mathrm{~S}$ rRNA marker. In particular, we analysed the L7 stem-loop folding models since this small region proved to be very variable (Figures 2 and 3, Figures S3 and S4). Two groups of nucleotide positions can be observed in the L7 stem-loop of the members grouped in Dondice clade (Figure 1): the first group is more variable and was diagnostic for species identification, while the second one includes nucleotides shared by all the taxa of the clade, and for this reason, could be very useful as a source of landmarks able to delimit the genus (Figure S4). Differences in nucleotides usually occur within the loop region and not in the stem, since the latter is under base-pairing 
constraints, which is what happens in the L7 stem-loop of Dondice spp. where no CBCs nor semiCBCs have been observed. The ability showed by the 2D folding structures of the $16 \mathrm{~S}$, and, in particular, by its small L7 loop, to give useful information at both species and genus taxonomic levels is quite important and reported here for the first time also at the genus level. This consideration becomes even more evident if we consider that, to improve results from phylogenetic analyses and from other methods of species delimitation, we are forced to exclude the hypervariable and unreliable regions of the 16S marker from our dataset, as strongly suggested by authoritative works [21-23]. The possibility to recover such a small but very significative region that would be otherwise lost constitutes an opportunity that must be considered.

The results from the phylogenetic approach and 16S rRNA 2D structures analyses are congruent with each other and yield a similar scenario, demonstrating the power of integrating these two methods. According to the results obtained, it is proposed that the species Nanuca sebastiani, currently included in the family Facelinidae and in the monospecific genus Nanuca, should be included in the genus Dondice (and consequently, moved to the family Myrrhinidae) as Dondice sebastiani comb. nov., with the genus Nanuca regarded as a synonym of Dondice. On the contrary, Dondice banyulensis, historically included in the genus Dondice, must be removed from the latter genus and ascribed as the type species of the new genus Nemesis gen. nov. here described, as Nemesis banyulensis comb. nov. Some very important ecological and morphological characters strongly support Nemesis gen. nov. within the Myrrhinidae. First of all, there is an ethological character (which indeed reflects the structural physiological difference) that appeared in the family after Nemesis banyulensis speciated, which became the synapomorphy of all the other apical genera (i.e., Hermissenda, Dondice, Godiva and Phyllodesmium): the ability to autotomise single or groups of cerata when under a predator's attack or when in stressed conditions (showed in the black circle in Figure 1). This behaviour was a fundamental turning point in the evolution of these clades, as it constituted a new defensive strategy that was effective in increasing the survival skills of these shell-less sea slugs; in situ and laboratory observations confirm that Nemesis banyulensis does not perform cerata autotomy [31]. From a morphological and anatomical points of view, there are two other features that support the validity of Nemesis gen. nov.: (i) in the new genus, the radula lacks a prominent cusp, which is, instead, characteristic of the related genera (i.e., Dondice (see [31], Figure 4F), Hermissenda, Godiva and Phyllodesmium\}. The median cusp of the radular tooth in Nemesis gen. nov. is not accentuated (Figure 5f); (ii) in Nemesis gen. nov., the distal and proximal male duct of the reproductive system is very long (Figure S2), which is typically different from other related genera (e.g., Dondice and Godiva see [31] Figure 5F). The results from morphological, ecological, molecular and 16S 2D structure analyses were congruent with each other, revealing the power of integrating evidence from several methods. In particular, the 'molecular morphology' approach revealed to be effective in this group of eolid nudibranchs, being able to give information at species and genera levels by looking at few diagnostic nucleotides. In fact, the diagnostic nucleotides associated to the 16S rRNA L7 stem-loop can be considered landmarks useful to separate at both genus and species levels in the family Myrrhinidae.

\section{Conclusions}

We have analysed the secondary structure of the $3^{\prime}$ half portion of the $16 \mathrm{~S}$ rRNA gene in the representative species of five genera, i.e., Dondice, Nanuca, Godiva, Hermissenda and Phyllodesmium, searching for short variable regions displaying diagnostic nucleotides. Among the variable 16S rRNA stem-loops, the L7 resulted to be the most divergent and it was taken into consideration as a short 2D RNA barcoding region. The 2D folding analysis of this 19 nucleotides-long region produced the same phylogenetic relationship obtained with the Bayesian and Maximum Likelihood analysis on the concatenated H3, 16S and COI alignment (1232 nucleotides), pointing out the resolution power of the "molecular morphology" approach when integrated with the standard use of the primary sequence. 
We confirm the validity of the genera Godiva, Hermissenda and Phyllodesmium as traditionally conceived, while we propose to exclude Dondice banyulensis from the genus Dondice and to assign it as the type species of the new genus Nemesis gen. nov. Furthermore, the monospecific genus Nanuca is here synonymised with the Dondice genus, and consequently, the taxon Nanuca sebastiani is renamed to Dondice sebastiani comb. nov.

Supplementary Materials: The following are available online at https:/ /www.mdpi.com/article/ 10.3390/life11060583/s1, Figure S1: Bayesian phylogenetic tree based on the single 16S dataset. Bayesian posterior probability (left) and Bootstrap (right) values are indicated at each node. Figure S2: Drawing of the reproductive system of Nemesis banyulensis comb. nov. (Voucher RM3_290) performed using optical microscope. Legend: $\mathrm{amp}=$ ampulla, $\mathrm{bc}=$ bursa copulatory, $\mathrm{dd}=$ deferent duct, fgm $=$ female gland mass, $\mathrm{md}=$ male duct, $\mathrm{p}=$ penis, $\mathrm{rs}=$ receptaculum seminis, $\mathrm{v}=$ vagina . Figure S3: (a) Folding models of the $16 \mathrm{~S}$ rRNA V domain of D. occidentalis, D. sebastiani comb. nov. and N. banyulensis comb. nov. analysed in the present work. The L7-11 stem-loops are boxed. (b) The variable L9-11 stem-loops are encircled to show differences occurring among the three taxa. Figure S4: L7 stem-loops of the species here analysed. (a) Primary sequence alignment of the L7 stem-loops among the Dondice spp. and N. banyulensis comb. nov. (b) Folding models of the L7 stem-loops. Blue circles indicate conserved nucleotide positions within the Dondice clade and red circles indicate diagnostic nucleotides.

Author Contributions: Conceptualisation, G.F. and P.M.; Data curation, G.F.; Formal analysis, G.F. and P.M.; Investigation, G.F.; Methodology, P.M.; Resources, G.F.; Supervision, P.M.; Writing—original draft, G.F. and P.M.; Writing—review and editing, G.F. and P.M. Both authors have read and agreed to the published version of the manuscript.

Funding: The APC was funded by the Italian Ministry of Education, grant AIM 1848751-2, Linea 2.

Institutional Review Board Statement: Not applicable.

Informed Consent Statement: Not applicable.

Data Availability Statement: Data available in a publicly accessible repository that does not issue DOIs. Publicly available datasets were analysed in this study. This data can be found here: [https://www.ncbi.nlm.nih.gov/].

Acknowledgments: The authors are indebted to Marcella D'Elia (Department of Mathematics and Physics of the University of Salento, Lecce, Italy) for the SEM pictures of the buccal structures and to Michele Solca (Milan, Italy) for the underwater pictures of living specimens. The authors wish to thank Marco Oliverio (La Sapienza University, Rome, Italy) and Egidio Trainito (Marine Protected Area 'Tavolara Punta Coda Cavallo', Olbia, Italy) for their useful suggestions that improved the quality of the present paper. Bernard Picton (Northern Ireland, UK) is acknowledged for the English language editing of the manuscript. Authors wish to thank the three anonimous reviewers for improving the quality of the manuscript. G.F. and P.M. received financial support from the University of Salento and the University Roma Tre. G.F. is supported by funds from the Italian Ministry of Education, University and Research (MIUR, PON 2014-2020, grant AIM 1848751-2, Linea 2).

Conflicts of Interest: The authors declare no conflict of interest. The funder had no role in the design of the study; in the collection, analyses or interpretation of data; in the writing of the manuscript, or in the decision to publish the results.

\section{References}

1. Goodheart, J.A.; Bleidißel, S.; Schillo, D.; Strong, E.; Ayres, D.L.; Preisfeld, A.; Collins, A.G.; Cummings, M.P.; Wägele, H. Comparative morphology and evolution of the cnidosac in Cladobranchia (Gastropoda: Heterobranchia: Nudibranchia). Front. Zool. 2018, 15, 1-18. [CrossRef]

2. Ekimova, I.; Korshunova, T.; Schepetov, D.; Neretina, T.; Sanamyan, N.; Martynov, A. Integrative systematics of northern and Arctic nudibranchs of the genus Dendronotus (Mollusca, Gastropoda), with descriptions of three new species. Zool. J. Linn. Soc. 2015, 173, 841-886. [CrossRef]

3. Padula, V.; Bahia, J.; Stöger, I.; Camacho-García, Y.; Malaquias, M.A.E.; Cervera, J.L.; Schrödl, M. A test of color-based taxonomy in nudibranchs: Molecular phylogeny and species delimitation of the Felimida clenchi (Mollusca: Chromodorididae) species complex. Mol. Phylogenetics Evol. 2016, 103, 215-229. [CrossRef] [PubMed] 
4. Schillo, D.; Wipfler, B.; Undap, N.; Papu, A.; Boehringer, N.; Eisenbarth, J.H.; Waegele, H. Description of a new Moridilla species from North Sulawesi, Indonesia (Mollusca: Nudibranchia: Aeolidioidea)—Based on MicroCT, histological and molecular analyses. Zootaxa 2019, 4652, 265-295. [CrossRef] [PubMed]

5. Fernández-Vilert, R.; Giribet, G.; Salvador, X.; Moles, J. Assessing the systematics of Tylodinidae in the Mediterranean Sea and Eastern Atlantic Ocean: Resurrecting Tylodina rafinesquii Philippi, 1836 (Heterobranchia: Umbraculida). J. Molluscan Stud. 2021, 87, eyaa031. [CrossRef]

6. Furfaro, G.; Salvi, D.; Mancini, E.; Mariottini, P. A multilocus view on Mediterranean aeolid nudibranchs (Mollusca): Systematics and cryptic diversity of Flabellinidae and Piseinotecidae. Mol. Phylogenetic Evol. 2018, 118, 13-22. [CrossRef]

7. Furfaro, G.; Salvi, D.; Trainito, E.; Vitale, F.; Mariottini, P. When morphology does not match phylogeny: The puzzling case of two sibling nudibranchs (Gastropoda). Zool. Scr. 2021, 1-16. [CrossRef]

8. Dayrat, B. Towards integrative taxonomy. Biol. J. Linn. Soc. 2005, 85, 407-417. [CrossRef]

9. Will, K.W.; Mishler, B.D.; Wheeler, Q.D. The perils of DNA barcoding and the need for integrative taxonomy. Syst. Biol. 2005, 54, 844-851. [CrossRef]

10. Pola, M.; Cervera, J.L.; Gosliner, T.M. Phylogenetic relationships of Nembrothinae (Mollusca: Doridacea: Polyceridae) inferred from morphology and mitochondrial DNA. Mol. Phylogenetics Evol. 2007, 43, 726-742. [CrossRef]

11. Pola, M.; Camacho-Garía, Y.E.; Gosliner, T.M. Molecular data illuminate cryptic nudibranch species: The evolution of the Scyllaeidae (Nudibranchia: Dendronotina) with a revision of Notobryon. Zool. J. Linn. Soc. 2012, 165, 311-336. [CrossRef]

12. Furfaro, G.; Modica, M.V.; Oliverio, M.; Mariottini, P. A DNA-barcoding approach to the phenotypic diversity of Mediterranean species of Felimare Ev. Marcus \& Er. Marcus, 1967 (Mollusca: Gastropoda), with a preliminary phylogenetic analysis. Ital. J. Zool. 2016, 83, 195-207. [CrossRef]

13. Bensasson, D.; Zhang, D.X.; Hartl, D.L.; Hewitt, G.M. Mitochondrial pseudogenes: Evolution's misplaced witnesses. Trends Ecol. Evol. 2001, 16, 314-321. [CrossRef]

14. Ballard, J.W.O.; Whitlock, M.C. The incomplete natural history of mitochondria. Mol. Ecol. 2004, 13, 729-744. [CrossRef] [PubMed]

15. Hebert, P.D.N.; Stoeckle, M.Y.; Zemlak, T.S.; Francis, C.M. Identification of birds through DNA barcodes. PLoS Biol. 2004, 2, e312. [CrossRef] [PubMed]

16. Moritz, C.; Cicero, C. DNA Barcoding: Promise and Pitfalls. PLoS Biol. 2004, 2, e354. [CrossRef]

17. Galià-Camps, C.; Carmona, L.; Cabrito, A.; Ballesteros, M. Double trouble. A cryptic first record of Berghia marinae Carmona, Pola, Gosliner, \& Cervera 2014 in the Mediterranean Sea. Mediterr. Mar. Sci. 2020, 21, 191-200. [CrossRef]

18. Furfaro, G.; Picton, B.; Martynov, A.; Mariottini, P. Diaphorodoris alba Portmann \& Sandmeier, 1960 is a valid species: Molecular and morphological comparison with D. luteocincta (M. Sars, 1870). Zootaxa 2016, 4193, 304-316.

19. Greber, B.J.; Ban, N. Structure and Function of the Mitochondrial Ribosome. Annu. Rev. Biochem. 2016, 85, 103-132. [CrossRef]

20. Castresana, J. Selection of conserved blocks from multiple alignments for their use in phylogenetic analysis. Mol. Biol. Evol. 2000, 17, 540-552. [CrossRef]

21. Talavera, G.; Castresana, J. Improvement of phylogenies after removing divergent and ambiguously aligned blocks from protein sequence alignments. Syst. Biol. 2007, 56, 564-577. [CrossRef] [PubMed]

22. Privman, E.; Penn, O.; Pupko, T. Improving the performance of positive selection inference by filtering unreliable alignment regions. Mol. Biol. Evol. 2012, 29, 1-5. [CrossRef] [PubMed]

23. Kück, P.; Meusemann, K.; Dambach, J.; Thormann, B.; von Reumont, B.M.; Wägele, J.W.; Misof, B. Parametric and non-parametric masking of randomness in sequence alignments can be improved and leads to better resolved trees. Front. Zool. 2010, 7, 1-12. [CrossRef]

24. Salvi, D.; Bellavia, G.; Cervelli, M.; Mariottini, P. The analysis of rRNA Sequence-Structure in phylogenetics: An application to the family Pectinidae (Mollusca, Bivalvia). Mol. Phylogenetics Evol. 2010, 56, 1059-1067. [CrossRef]

25. Salvi, D.; Macali, A.; Mariottini, P. Molecular phylogenetics and systematics of the bivalve family Ostreidae based on rRNA sequence-structure models and multilocus species tree. PLoS ONE 2014, 9, e108696. [CrossRef] [PubMed]

26. Salvi, D.; Mariottini, P. Molecular phylogenetics in 2D: ITS2 rRNA evolution and sequence-structure barcode from Veneridae to Bivalvia. Mol. Phylogenetics Evol. 2012, 65, 792-798. [CrossRef]

27. Salvi, D.; Mariottini, P. Molecular taxonomy in 2D: A novel ITS2 rRNA sequence-structure approach guides the description of the oysters' subfamily Saccostreinae and the genus Magallana (Bivalvia: Ostreidae). Zool. J. Linn. Soc. 2017, 179, 263-276. [CrossRef]

28. Müller, T.; Philippi, N.; Dandekar, T.; Schultz, J.; Wolf, M. Distinguishing species. RNA 2007, 13, 1469-1472. [CrossRef]

29. Furfaro, G.; Mariottini, P.; Modica, M.V.; Trainito, E.; Doneddu, M.; Oliverio, M. Sympatric sibling species: The case of Caloria elegans and Facelina quatrefagesi (Gastropoda: Nudibranchia). Sci. Mar. 2016, 80, 511-520. [CrossRef]

30. Lydeard, C.; Holznagel, W.E.; Schnare, M.N.; Gutell, R.R. Phylogenetic analysis of molluscan mitochondrial LSU rDNA sequences and secondary structures. Mol. Phylogenetics Evol. 2000, 15, 83-102. [CrossRef]

31. Furfaro, G.; Mariottini, P. A new Dondice Marcus Er. 1958 (Gastropoda: Nudibranchia) from the Mediterranean Sea reveals interesting insights into the phylogenetic history of a group of Facelinidae taxa. Zootaxa 2020, 477731, 1-22. [CrossRef] [PubMed]

32. Martynov, A.; Mehrotra, R.; Chavanich, S.; Nakano, R.; Kashio, S.; Lundin, K.; Korshunova, T. The extraordinary genus Myja is not a tergipedid, but related to the Facelinidae s. str. with the addition of two new species from Japan (Mollusca, Nudibranchia). ZooKeys 2019, 818, 89. [CrossRef] 
33. Neary, J.T.; Alkon, D.L. Protein phosphorylation/dephosphorylation and the transient, voltage-dependent potassium conductance in Hermissenda crassicornis. J. Biol. Chem. 1983, 258, 8979-8983. [CrossRef]

34. Croll, R.P. Distribution of monoamines in the central nervous system of the nudibranch gastropod, Hermissenda crassicornis. Brain Res. 1987, 405, 337-347. [CrossRef]

35. Blackwell, K.T.; Alkon, D.L. Ryanodine receptor modulation of in vitro associative learning in Hermissenda crassicornis. Brain Res. 1999, 822, 114-125. [CrossRef]

36. Kasheverov, I.E.; Shelukhina, I.V.; Kudryavtsev, D.S.; Makarieva, T.N.; Spirova, E.N.; Guzii, A.G.; Tsetlin, V.I. 6-Bromohypaphorine from marine nudibranch mollusk Hermissenda crassicornis is an agonist of human $\alpha 7$ nicotinic acetylcholine receptor. Mar. Drugs 2015, 13, 1255-1266. [CrossRef]

37. Tamvacakis, A.N.; Senatore, A.; Katz, P.S. Identification of genes related to learning and memory in the brain transcriptome of the mollusc, Hermissenda crassicornis. Learn. Mem. 2015, 22, 617-621. [CrossRef]

38. Lindsay, T.; Valdés, Á. The Model Organism Hermissenda crassicornis (Gastropoda: Heterobranchia) Is a Species Complex. PLoS ONE 2016, 11, e0154265. [CrossRef]

39. Merlo, E.M.; Milligan, K.A.; Sheets, N.B.; Neufeld, C.J.; Eastham, T.M.; Estores-Pacheco, A.K.A.; Wyeth, R.C. Range extension for the region of sympatry between the nudibranchs Hermissenda opalescens and Hermissenda crassicornis in the northeastern Pacific. Facets 2018, 3, 764-776. [CrossRef]

40. Wagner, D.; Kahng, S.E.; Toonen, R.J. Observations on the life history and feeding ecology of a specialized nudibranch predator (Phyllodesmium poindimiei), with implications for biocontrol of an invasive octocoral (Carijoa riisei) in Hawaii. J. Exp. Mar. Biol. Ecol. 2009, 372, 64-74. [CrossRef]

41. Mao, S.C.; Gavagnin, M.; Mollo, E.; Guo, Y.W. A new rare asteriscane sesquiterpene and other related derivatives from the Hainan aeolid nudibranch Phyllodesmium magnum. Biochem. Syst. Ecol. 2011, 39, 408-411. [CrossRef]

42. Bogdanov, A.; Hertzer, C.; Kehraus, S.; Nietzer, S.; Rohde, S.; Schupp, P.J.; Wägele, H.; König, G.M. Secondary metabolome and its defensive role in the aeolidoidean Phyllodesmium longicirrum, (Gastropoda, Heterobranchia, Nudibranchia). Beilstein J. Org. Chem. 2017, 13, 502-519. [CrossRef]

43. Ekimova, I.A.; Antokhina, T.I.; Schepetov, D.M. Molecular data and updated morphological description of Flabellina rubrolineata (Nudibranchia: Flabellinidae) from the Red and Arabian seas. Ruthenica 2020, 30, 183-194.

44. Tamura, K.; Stecher, G.; Peterson, D.; Filipski, A.; Kumar, S. MEGA6: Molecular evolutionary genetics analysis version 6.0. Mol. Biol. Evol. 2013, 30, 2725-2729. [CrossRef] [PubMed]

45. Posada, D. jModelTest: Phylogenetic Model Averaging. Mol. Biol. Evol. 2008, 7, 1253-1256. [CrossRef]

46. Ronquist, F.; Teslenko, M.; Van Der Mark, P.; Ayres, D.; Darling, A.; Höhna, S.; Larget, B.; Liu, L.; Suchard, M.A.; Huelsenbeck, J.P. MrBayes 3.2: Efficient Bayesian phylogenetic inference and model choice across a large model space. Syst. Biol. 2011, 61, 539-542. [CrossRef] [PubMed]

47. Rambaut, A.; Drummond, A.J.; Xie, D.; Baele, G.; Suchard, M.A. Posterior summarization in Bayesian phylogenetics using Tracer 1.7. Syst. Biol. 2018, 67, 901. [CrossRef] [PubMed]

48. Silvestro, D.; Michalak, I. raxmlGUI: A graphical front-end for RAxML. Org. Divers. Evol. 2012, 12, 335-337. [CrossRef]

49. Stamatakis, A. RAxML version 8: A tool for phylogenetic analysis and post-analysis of large phylogenies. Bioinformatics 2014, 30, 1312-1313. [CrossRef]

50. Zuker, M.; Jacobson, A.B. Using reliability information to annotate RNA secondary structures. RNA 1998, 4, 669-679. [CrossRef]

51. Zuker, M. Mfold web server for nucleic acid folding and hybridization prediction. Nucleic Acids Res. 2003, 31, 3406-3415. [CrossRef] [PubMed]

52. Mathews, D.H.; Sabina, J.; Zuker, M.; Turner, D.H. Expanded sequence dependence of thermodynamic parameters improves prediction of RNA secondary structure. J. Mol. Biol. 1999, 288, 911-940. [CrossRef] [PubMed]

53. Horovitz, I.; Meyer, A. Systematics of New World monkeys (Platyrrhini, Primates) based on $16 \mathrm{~S}$ mitochondrial DNA sequences: A comparative analysis of different weighting methods in cladistic analysis. Mol. Phylogenetics Evol. 1995, 4, 448-456. [CrossRef]

54. Jörger, K.M.; Norenburg, J.L.; Wilson, N.G.; Schrödl, M. Barcoding against a paradox? Combined molecular species delineations reveal multiple cryptic lineages in elusive meiofaunal sea slugs. BMC Evol. Biol. 2012, 12, 245. [CrossRef] [PubMed]

55. Portmann, A.; Sandmeier, E. Dondice banyulensis sp. nov. un Eolidien nouveau de la Méditerranée. Rev. Suisse Zool. 1960, 67, 158-168. [CrossRef]

56. Caterino, M.S.; Cho, S.; Sperling, F.A. The current state of insect molecular systematics: A thriving Tower of Babel. Annu. Rev. Entomol. 2000, 45, 1-54. [CrossRef]

57. Hebert, P.D.N.; Cywinska, A.; Ball, S.L.; de Waard, J.R. Biological identifications through DNA barcodes. Proc. R. Soc. Lond. Ser. B 2003, 270, 313-321. [CrossRef]

58. Hebert, P.D.N.; Ratnasingham, S.; de Waard, J.R. Barcoding animal life: Cytochrome c oxidase subunit 1 di-vergencesamong closely related species. R. Soc. Lond. Ser. B 2003, 270, S96-S99.

59. Stoeckle, M. Taxonomy, DNA, and the bar code of life. BioScience 2003, 53, 2-3. [CrossRef]

60. Avise, J.C. Molecular Markers, Natural History and Evolution, 2nd ed.; Sinauer: Sunderland, UK, 2004. 